\title{
Perbedaan Hasil Belajar Fisika antara Model Pembelajaran Berbasis Masalah dengan Model Pembelajaran Probing Prompting pada Siswa Kelas X SMAN I Bulu Taba Kab. Mamuju Utara
}

\author{
Windar dewi, Muslimin, dan Muhammad Ali \\ Windardewi@rocketmail.com \\ Program Studi Pendidikan Fisika FKIP Universitas Tadulako \\ Jl. Soekarno Hatta Km. 9 Kampus Bumi Tadulako Tondo Palu - Sulawesi Tengah
}

\begin{abstract}
Abstrak - Penelitian eksperimen ini bertujuan untuk mengetahui ada tidaknya perbedaan hasil belajar fisika antara model Pembelajaran Berbasis Masalah dengan model Pembelajaran Probing Prompting pada siswa kelas X SMAN 1 Bulu Taba Kab. Mamuju Utara. Jenis penelitian ini menggunakan metode quasi experimental design yang diterapkan pada dua kelas eksperimen khususnya pada kelas $\mathrm{X}$ dengan desain penelitiannya berupa "Posttest-Only Comparison Group Design" yaitu memilih kelas-kelas yang diperkirakan sama kondisinya. Pada pembelajaran PPP diperoleh nilai standar deviasi postestnya sebesar 2,80. Sedangkan pada pembelajaran PBM diperoleh nilai standar deviasi postestnya sebesar 3,68. Hasil pengujian hipotesis statistik uji rata-rata (uji t) yaitu $t_{\text {hitung }}=2,27$ dan harga $t_{\text {tabel }}=2,02$ pada taraf nyata $a=0,05$. Hal ini menunjukan bahwa harga $t_{\text {hitung }}>t_{\text {tabel }}$ sehingga nilai $t_{\text {hitung }}$ berada diluar daerah penerimaan $H_{0}$. Dengan demikian dapat disimpulkan bahwa ada perbedaan hasil belajar fisika siswa yang mengikuti model Pembelajaran Berbasis Masalah dengan model Pembelajaran probing prompting di kelas X SMAN 1 Bulu Taba Kab. Mamuju Utara.
\end{abstract}

Kata Kunci: Pembelajaran Berbasis Masalah, Pembelajaran Probing Prompting, Hasil Belajar.

\section{PENDAHULUAN}

Proses belajar mengajar guru berperan penting untuk mendapatkan hasil belajar maksimal. Guru merupakan kunci keberhasilan dan peningkatan siswa. Dalam Proses belajar siswa memiliki keaktifan dan kemampuan yang berbeda-beda dalam menyelesaikan masalah, ada siswa cenderung lebih aktif secara berkelompok dan ada juga cenderung lebih aktif secara individu. Dalam mengatasi masalah tersebut dibutuhkan model pembelajaran yang sesuai terhadap permasalahan siswa.

Model pembelajaran merupakan landasan praktik pembelajaran hasil penurunan teori psikologi pendidikan dan teori belajar berdasarkan analisis terhadap kurikuum dan implimentasinya pada tingkat oprasional dikelas [1].

Penelitian menerapkan model pembelajaran berbasis masalah (PBM) sebagai kelas eksperimen 1 dengan model pembelajaran probing prompting (PPP) sebagai kelas eksperimen 2. Model Pembelajaran Berbasis Masalah merupakan model pembelajaran yang dimulai dengan penyajian masalah yang nyata yang penyelesaian dibutuhkan kerja sama diantara siswa-siswa [2]. Penelitian sebelumnya yang mengkaji model PBM tentang Penerapan PBM pada materi gerak lurus berubah beraturan menyimpulkan bahwa model PBM dapat meningkatkan kemampuan berpikir kritis siswa [3].

Model pembelajaran probing prompting merupakan pembelajaran dengan cara guru menyajikan serangkaian pertanyaan yang sifatnya menuntun dan menggali sehingga terjadi proses berfikir yang mengaitkan pengetahuan siswa dan pengalamannya dengan pengetahuan yang baru yang sedang dipelajari. proses tanya jawab dengan menunjuk secara acak sehigga setiap siswa mau tidak mau harus berpartisipasi aktif [4]. Penelitian sebelumnya tentang penerapan pembelajaran probingprompting terhadap hasil belajar peserta didik pada materi lingkaran menyimpulkan bahwa hasil belajar peserta didik menggunakan probing promting telah memenuhi standar KKM dan ketuntasan peserta didik dengan penerapan probing prompting lebih banyak dibandingkan menerapkan pembelajaran konvensional [5].

Berdasarkan uraian di atas, penulis bermaksud untuk membedakan kedua model pembelajaran yaitu model PBM dengan model PPP.

\section{METODE PENELITIAN}

Desain atau rancangan pada penelitian ini menggunakan "Posttest-Only Comparison Group Design" atau Desain kelompok 
pembanding pasca tes beracak. Bentuk desainnya disajikan pada Tabel 1 [6].

\begin{tabular}{ccc}
\multicolumn{3}{c}{ TABEL 1. DESAIN PENELITIAN } \\
\hline Kelas & Perlakuan & Post-tes \\
\hline Eksperimen 1(PBM) & $\mathrm{X}_{1}$ & $\mathrm{O}$ \\
Eksperimen 2 (PPP) & $\mathrm{X}_{2}$ & 0
\end{tabular}

Keterangan :

$\mathrm{X}_{1}$ : Perlakuan untuk kelas eksperimen dengan menerapkan model pembelajaran berbasis masalah.

$\mathrm{X}_{2}$ : Perlakuan untuk kelas eksperimen dengan menerapkan model pembelajaran probing prompting.

Populasi dalam penelitian ini adalah seluruh siswa kelas X SMAN 1Bulu Taba. Dua kelas yang dijadikan tempat penelitian ini yaitu kelas eksperimen 1 dengan perlakuan menerapan model pembelajaran berbasis masalah dan kelas ekspeimen 2 yang di beri perlakuan dengan menerapkan model pembelajaran probing prompting.

Instrumen yang digunakan dalam penelitian ini adalah lembar kerja siswa (LKS), RPP, bahan ajar, tes hasil belajar fisika berupa objektif tes ( pilihan ganda ). Tes tersebut digunakan untuk mengetahui perbedaan hasil belajar fisika pada kedua kelas yang menjadi sampel penelitian. Tes dibuat dalam bentuk objektif tes, untuk memperoleh tes yang standar, dilakukan uji coba tes dan kemudian dianalisis untuk melihat validitas tes, daya pembeda, tingkat kesukaran dan reliabilitas tes.

\section{HASIL dan PEMBAHASAN}

\section{A. Hasil Peneltian}

Pada penelitian terdiri dari kelas eksperimen PBM dengan jumlah 20 siswa dan kelas PPP dengan jumlah 24. Kemudian diberikan postest (tes akhir) Skor rata-rata kelas eksperimen PBM sebesar 18,00 dengan standar deviasi sebesar 3,68 sedangkan skor rata-rata kelas eksperimen sebesar 15,83 dengan standar deviasi 2,80.

Pengujian data pada penelitian ini menggunakan uji normalitas, uji homogenitas, dan uji hipotesis. Untuk uji normalitas menggunakan chikuadrat dengan kriteria penerimaan $x_{\text {hitung }}^{2}<x_{\text {tabel }}^{2}$, taraf signifikan $\alpha$ $=0,05$ dan derajat kebebasan $\mathrm{dk}=\mathrm{k}-3$. Data yang digunakan untuk menguji normalitas meliputi posttest baik kelas eksperimen PBM maupun kelas eksperimen PPP. Berdasarkan hasil perhitungan atau pengolahan data, hasil pengujian normalitas untuk postest pada kelas eksperimen PBM $x_{\text {hitung }}^{2}=2,66$ sedangkan $x_{\text {tabel }}^{2}=7,81$ dan kelas eksperimen PPP $x_{\text {hitung }}^{2}$ $=3,45$ sedngkan $x_{\text {tabel }}^{2}=5,99$. hal ini menunjukkan bahwa data berdistribusi normal.

Uji homogenitas pada penelitian ini menggunakan $u j i$ statistik $F$ dengan taraf signifikansi $\alpha=0,05$ dan nilai varians kelas eksperimen PPP sebesar 9,39 serta kelas eksperimen PBM sebesar 10,62. berdasarkan hasil perhitungan, diperoleh nilai $F_{\text {hitung }}$ Sebesar 1,13 sedangkan nilai $F_{\text {tabel }}$ sebesar 2,02. Hal ini menunjukkan kedua kelas yang dijadikan sampel berasal dari populasi yang homogen

Berdasarkan nilai rata-rata posttest kelas eksperimen PPP sebesar 15,83 dan kelas eksperimen PBM sebesar 18,00. Dilakukan uji hipotesis (uji-t) beda rata-rata (dua pihak) dan diketahui nilai thitung $=2,27$. Selanjutnya untuk nilai tabel dimana tabel $=2,02$

Adapun data hasil penelitian di atas, disajikan pada Tabel 2 :

TABEL 2 UJI BEDA RATA-RATA (DUA PIHAK) KELAS EKSPERIMEN PPP DAN

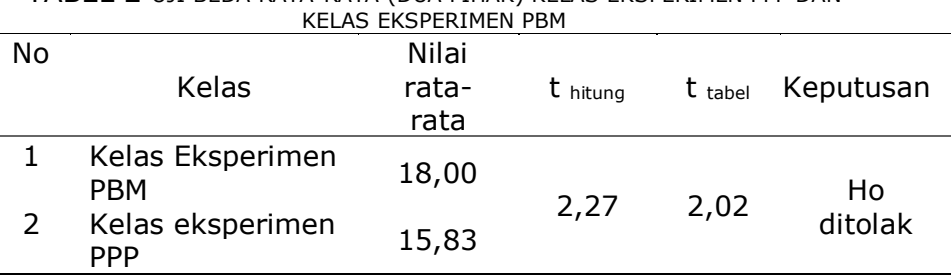

Setelah dilakukan uji normalitas dan homogenitas, maka dilanjutkan dengan uji beda rata-rata atau uji t. dimana $\mathrm{H}_{1}$ diterima jika Jika $-t_{(1-0,5 \alpha)}<t<t_{(1-0,5 \alpha)}$ diketahui data dari postest yaitu thitung $=2,27$ dan harga tabel $=$ 2,02 . Hal ini menunjukkan bahwa thitung berada diluar daerah penerimaan Ho. Dengan demikian $\mathrm{H}_{1}$ diterima dan $\mathrm{H}_{0}$ ditolak. Artinya bahwa terdapat perbedaan hasil belajar fisika antara model pembelejaran berbasis masalah dengan model pembelajan probing-prompting pada siswa kelas X SMAN 1 Bulu Taba Kab. Mamuju Utara

\section{B. Pembahasan}

Tujuan penelitian in yaitu untuk mengetahui ada tidaknya perbedaan hasil belajar fisika antara model pembelajaran berbasis masalah dengan model pembelajaran probing prompting pada siswa kelas $X$ SMAN 1 Bulu Taba kab.mamuju utara. Model PBM merupakan model pembelajaran yang menimbulkan permasalah yang dapat membuat siswa lebih aktif dan permsalahan yang ditimbulkan dapat diselesaikan secara berkelompok sedangka model PPP merupakann model pembelajaran yang dapat membuat siswa lebih aktif, siswa 
diberikan sebuah pertanyaan atau permasalah yang dapat menggali pengetahuannya sendiri sehingga siswa bisa lebih mandiri untuk mengembangkan pengetahuannya.

Adapun Adapun nilai yang diperoleh dalam perhitungan Uji-t dua pihak yang telah dilakukan oleh peneliti berdasarkan hasil skor posttest pada kedua kelas eksperimen diperoleh nilai thitung $=2,27$ dan nilai tabel $=2,02$. Dengan menggunakan kriteria $\mathrm{H}_{\mathrm{o}}$ diterima jika - $\mathrm{t}(1-$ $0,5 a)<t(1-0,5 a)$, hal ini menunjukkan bahwa nilai thitung berada diluar penerimaan $\mathrm{H}_{\mathrm{o}}$. Dengan demikian $\mathrm{H}_{0}$ ditolak dan $\mathrm{H}_{1}$ diterima, hal ini berarti terdapat perbedaan hasil belajar antara kelas yang mendapatkan pembelajaran menggunakan model pembelajaran berbasis masalah dengan model pembelajaran probing prompting. Terdapat perbedaan hasil belajar setelah perlakuan tiap kelas. Perbedaan itu dikarenakan perlakuan antara kedua kelas berbeda dalam pelaksanaan pembelajarannya

Kedua model pembelajaran yang digunakan pada setiap kelas eksperimen dapat meningkatkan hasil belajar fisika siswa. Nilai rata-rata postest pada kelas eksperimen PBM yaitu $X_{1}=18,00$ dan kelas eksperimen PPP yaitu $X_{2}=15,83$.

Berdasarkan nilai rata-rata postest dari kedua model pembelajaran yang diterapkan pada kedua kelas eksperimen menunjukan bahwa nilai hasil belajar fisika siswa yang menerapkan model pembelajaran pbm lebih besar dengan nilai rata-rata yaitu 72,00 dibandingkan dengan nilai hasil belajar fisika yang menerapkan model pembelajaran ppp dengan nilai 60,32. Perbedaan yang terjadi pada kedua kelas eksperimen pada Model PBM lebih besar dibanding dengan model PPP, hal ini disebabkan model PBM dapat melakukan praktikum karena pembelajaran berkolompok sehingga siswa memperoleh pengetahuan secara langsung. Dibandingkan dengan model PPP melakukan pengamatan sendiri sehingga tidak bisa melakukan praktikum. Selain itu pada Model PBM penyelesaiannya masalah secara berkelompok sehingga daat membantu siswa yang lainnya.

Kelebihan model pembelajaran berbasis masalah yaitu dapat menyetarakan kemampuan siswa yang berbeda-beda, karena siswa merumuskan hipotesis dengan berdiskusi sehingga dapat membantu siswa untuk saling melengkapi pengetahuannya, dapat meningkatkan motivasi belajar siswa dalam menemukan pengatahuannya melalui belajar dengan kebersamaan, dapat memperoleh pengetahuan yang lebih maksimal, karena pengetahuan yang diperoleh melalui sebuah penemuan yang disertai dengan proses kebersamaan. Memaksimalkan pengetahuan siswa melalui bimbingan guru, kebersamaan belajar dengan proses diskusi dalam merumuskan hipotesis. Sedangkan kekurangan model pembelajaran bebasis masalah yaitu Pada saat penyeselesaian masalah semua kelompok butuh dibimbingan.

Kelebihan model pembelajaran probing promting yaitu pada saat proses pembelajaran berlangsung, beberapa siswa tidak terfokus terhadap pembelajaran kemudian guru memberikan beberapa pertanyaan agar siswa terfokus kembali, siswa dapat belajar secara mandiri dari beberapa pertanyaan atau permasalahan yang diberikan oleh guru. Sedangkan kekurangan model pembelajaran probing prompting yaitu semua siswa perlu bimbingan ketika dipermasalahan, waktu yang tidak efesien, ketika siswa diberika pertanyaan atau permasalahan tidak semua dapat menjawabnya.

\section{KESIMPULAN}

Berdasarkan hasil pengolaan data dan hasil pengujian hiotesis maka dapat disimpulkan bahwa terdapat perbedaan hasil belajar fisika antara model pembelejaran berbasis masalah dengan model pembelajan probing-prompting pada siswa kelas X SMAN 1 Bulu Taba Kab. Mamuju Utara. Hal tersebut bedasarkan hasil uji hiotesis yaitu uji t dengan $-t_{(1-0,5 \alpha)}<t<t_{(1-0,5 \alpha)}$ dengan taraf nyata $\mathrm{a}=$ 0,05 yaitu thitung $=2,27$ dan harga tabel $=2,02$. Kriteria pengujian adalah $\mathrm{H}_{\mathrm{o}}$ diterimah jika $2,00<t<2,02$. Hal ini menunjukkan bahwa nilai thitung berada diluar daerah penerimaan $\mathrm{H}_{\mathrm{o}}$. dengan demikian $\mathrm{H}_{\mathrm{o}}$ ditolak dan $\mathrm{H}_{1}$ diterima.

\section{DAFTAR PUSTAKA}

[1] Suprijono, Agus. 2009. Cooperative Learning Teori \& Aplikasi Paikem. Yokyakarta : Pustaka Pelajar

[2] Trianto. 2009. Mendesain Model Pembelajaran InovatifProgresif. Jakarta : Prenada media Group

[3] Setyorini, u .2011. "Penerapan Model Beased Learning Untuk Meningkatkan Kemampuan Berpikir Kritis Siswa Smp". Jurnal Pendidikan Fisika Indonesia 7 (2011) 52-56

[4] Muslimin. 2009. 80 Model dan Pendekatan Pembelajaran Inovatif. Palu : Penerbit Tadulako

[5] Swasono. 2014. "Penerapan Pembelajaran ProbingPrompting Terhadap Hasil Belajar Peserta Didik Pada Materi Lingkaran". Unnes Journal of Mathematics Education Universitas Negeri Semarang , ISSN 22526927

[6] Syaodih S, Nana. 2005. Metode Penelitian Pendidikan. Bandung : Rineka Cipta 